\title{
Combating the COVID-19 Pandemic: Experiences of the First Wave From Nepal
}

\author{
Buddha Bahadur Basnet ${ }^{1 \dagger}$, Kiran Bishwakarma ${ }^{2 \dagger}$, Ramesh Raj Pant ${ }^{3}$, Santosh Dhakal ${ }^{4}$, \\ Nashib Pandey ${ }^{5}$, Dhruba Gautam ${ }^{6}$, Archana Ghimire ${ }^{2}$ and Til Bahadur Basnet ${ }^{7 *}$ \\ ${ }^{1}$ Faculty of Science, Nepal Academy of Science and Technology, Lalitpur, Nepal, ${ }^{2}$ Nepal Environment and Development \\ Consultant Pvt. Ltd., Kathmandu, Nepal, ${ }^{3}$ Central Department of Environmental Science, Institute of Science and \\ Technology, Tribhuvan University, Kathmandu, Nepal, ${ }^{4}$ Nepal Development Society, Bharatpur, Nepal, ${ }^{5}$ Kantipur Dental \\ College Teaching Hospital and Research Center, Kathmandu University, Kathmandu, Nepal, ${ }^{6}$ National Disaster Risk \\ Reduction Centre, Kathmandu, Nepal, ${ }^{7}$ Little Buddha College of Health Sciences, Kathmandu, Nepal
}

Unprecedented and unforeseen highly infectious Coronavirus Disease 2019 (COVID-19) has become a significant public health concern for most of the countries worldwide, including Nepal, and it is spreading rapidly. Undoubtedly, every nation has taken maximum initiative measures to break the transmission chain of the virus. This review presents a retrospective analysis of the COVID-19 pandemic in Nepal, analyzing the actions taken by the Government of Nepal $(\mathrm{GoN})$ to inform future decisions. Data used in this article were extracted from relevant reports and websites of the Ministry of Health and Population (MoHP) of Nepal and the WHO. As of January 22, 2021, the highest numbers of cases were reported in the megacity of the hilly region, Kathmandu district (population $=1,744,240$ ), and Bagmati province. The cured and death rates of the disease among the tested population are $\sim 98.00$ and $\sim 0.74 \%$, respectively. Higher numbers of infected cases were observed in the age group 21-30, with an overall male to female death ratio of 2.33. With suggestions and recommendations from high-level coordination committees and experts, GoN has enacted several measures: promoting universal personal protection, physical distancing, localized lockdowns, travel restrictions, isolation, and selective quarantine. In addition, GoN formulated and distributed several guidelines/protocols for managing COVID-19 patients and vaccination programs. Despite robust preventive efforts by GoN, pandemic scenario in Nepal is, yet, to be controlled completely. This review could be helpful for the current and future effective outbreak preparedness, responses, and management of the pandemic situations and prepare necessary strategies, especially in countries with similar socio-cultural and economic status.

Keywords: COVID-19, pandemic, preparedness, response, spatial distribution, public health, Nepal

\section{INTRODUCTION}

The unanticipated outbreak of the novel coronavirus was first reported in Wuhan, China, in December 2019; it transmits from human to human via droplets and aerosol (1). The WHO declared Coronavirus Disease 2019 (COVID-19) as a Public Health Emergency of International Concern (PHEIC) on January 30, 2020, and a pandemic on March 11, 2020 (2). As a result, countries 
worldwide adopted various mitigative measures $(3,4)$ and eradication strategies (5), aiming to reduce potentially enormous damage and reach zero cases, respectively. However, significant gaps in advance preparedness and the implementation of response plans resulted in the rapid spread of severe acute respiratory syndrome coronavirus-2 (SARS-CoV-2) globally with 219 nations reporting it as of January $22,2021^{1}$ (6).

The Federal Democratic Republic of Nepal is a landlocked country in South Asia bordered by India in the south, east, and west, and China in the north. Its population, gross domestic product (GDP), and human development index (HDI) are 29.24 million $^{2}, 30.64$ billion $^{3}$, and $0.579^{4}$, respectively. The constitution of Nepal (2015) consists of a three-tier (federal, province, and local) governmental system. Each tier has the constitutional power to enact laws and mobilize its resources. In Nepal, the first case of COVID-19 was reported on January 23, 2020, in a 32year-old Nepalese man who returned from Wuhan, China. Two months after the first case, the second case was diagnosed through domestic testing on March 23 in a returnee from France (7). Subsequently, the Government of Nepal (GoN) imposed early interventions approved by the WHO, including a travel ban and the Indo-Nepal and China-Nepal borders closure ${ }^{5}$ (8) to delay the possible onset of the detrimental effects of the outbreak across the country.

This review presents a 1-year (up to January 22, 2021) scenario of COVID-19 in Nepal, reviews the strategies employed by the GoN to control COVID-19, and provides suggestions for the prevention and control of current and future pandemics. Federal, provincial, and district-level daily cases of COVID-19 [confirmed by real-time PCR (qRT-PCR), cured, and death] in Nepal from January 23, 2020, to January 22, 2021, were obtained from the Ministry of Health and Population (MoHP), $\mathrm{GoN}^{6}$. Searches using the website of MoHP of Nepal, PubMed, the WHO, the worldometer official website, and Google were conducted to gather the information on the number of deaths, cured, and confirmed cases of COVID-19 and reports describing the approach taken by the government to contain COVID-19 in Nepal. The search terms included "COVID19 in Nepal" and "Prevention and management of COVID19 in Nepal." Data used in this article were extracted from relevant documents and websites. The figures were constructed by using Origin 2016 and GIS 10.4.1. We did not consult

\footnotetext{
${ }^{1}$ Worldometer. COVID-19 Coronavirus Pandemic. (2020). Available online at: https:/www.worldometers.info/coronavirus/ (accessed January 15, 2021).

${ }^{2}$ Worldometer. Nepal Population. (2020). Available online at: https://www. worldometers.info/world-population/nepal-population/ (accessed January 15, 2021).

${ }^{3}$ Trading Economics. Nepal GDP. (2020). Available online at: https:// tradingeconomics.com/nepal/gdp (accessed January 15, 2021).

${ }^{4}$ UNDP. Human Development Reports. (2020). Available online at: http://hdr. undp.org/en/countries/profiles/NPL (accessed January 15, 2021).

${ }^{5}$ World Health Organization. COVID-19 Nepal: Preparedness and Response Plan (NPRP). (2020). Available online at: https://www.who.int/docs/defaultsource/nepal-documents/novel-coronavirus/covid-19-nepal-preparedness-andresponse-plan-(nprp)-draft-april-9.pdf?sfvrsn=808a970a_2 (accessed January 15, 2021).

${ }^{6}$ Ministry of Health and Population. COVID-19 Update. (2020). Available online at: https://covid19.mohp.gov.np/ (accessed January 15, 2021).
}

TABLE 1 | Prevalence and case fatality ratio (CFR) of COVID-19 of top leading countries, neighbor countries of Nepal, and SAARC as of Jan 28, 2021.

\begin{tabular}{lll}
\hline Countries & $\begin{array}{c}\text { Prevalence ratio on } \\
\text { tested population }(\%)\end{array}$ & Case fatality ratio (\%)
\end{tabular}

\section{TOP LEADING COUNTRIES}

$\begin{array}{lcc}\text { USA } & 8.596 & 2.687 \\ \text { Brazil } & 31.681 & 2.721 \\ \text { Russia } & 3.767 & 2.170 \\ \text { NEIGHBOR COUNTRIES } & & \\ \text { India* } & 0.099 & 1.460 \\ \text { China } & 0.055 & 5.297 \\ \text { SAARC } & & \\ \text { Nepal } & 13.129 & 0.755 \\ \text { Pakistan } & 6.910 & 2.275 \\ \text { Bangladesh } & 14.769 & 1.661 \\ \text { Bhutan } & 0.188 & 0.128 \\ \text { Sri Lanka } & 3.710 & 0.542 \\ \text { Maldives } & 3.867 & 0.099 \\ \text { Afghanistan } & 22.281 & 4.799\end{array}$

*Belong to SAARC and top leading countries.

any databases that are privately owned or inaccessible to the public.

\section{EPIDEMIC STATUS OF COVID-19 IN NEPAL}

The MoHP of Nepal confirmed the first and second cases of COVID-19, respectively, in January and March, in an interval of 2 months $^{1}$ (9). As of January 22, 2021, 268,948 COVID19 positive cases were reported, with 263,546 recovered, and 1,986 death cases ${ }^{6}$. This data showed nearly $0.74 \%$ death and about $98 \%$ recovery rate in Nepal. The case fatality rate (CFR) was $0.5 \%$ up to March 30 in Nepal (9). The CFR in the USA, Brazil, and Russia is similar ( 2\%), whereas in the South Asian Association of Regional Cooperation (SAARC) countries, the CFR varied from $\sim 0.09$ to $\sim 4.7 \%$ (Table 1 ). In total, 2,035,301 qRT-PCR tests were performed in Nepal, indicating about $13.47 \%$ current prevalence of COVID-19 among the qRTPCR tested population as compared with $2.5 \%$ as of March 31 , $2020^{2}$. As of reviewing, the prevalence of COVID-19 among the qRT-PCR tested population is higher than the neighboring countries, China $(\sim 0.055 \%)$ and India $(\sim 0.099 \%)$ (Table 1$)$. In addition, up to the third quarter of $2020,<1 \%$ of the confirmed COVID-19 cases were symptomatic across all age groups, while the proportion of symptomatic cases progressively increased beyond 55 years of age from 1.3 to $9 \%^{7,8}$. Unlike Nepal, higher

\footnotetext{
${ }^{7}$ World Health Organization. WHO Nepal Situation Updates-19 on COVID-19, 2020. (2020). Available online at: https://www.who.int/docs/default-source/nepaldocuments/novel-coronavirus/who-nepal-sitrep/19-who-nepal-sitrep-covid-19. pdf?sfvrsn=c9fe7309_2 (accessed January 15, 2021).

${ }^{8}$ World Health Organization. WHO Nepal Situation Updates-22 on COVID-19, 2020. (2020). Available online at: https://www.who.int/docs/default-source/nepaldocuments/novel-coronavirus/who-nepal-sitrep/22-who-nepal-sitrep-covid- 19. pdf?sfvrsn=df7c946a_2 (accessed January 15, 2021).
} 
symptomatic cases were reported from other parts of the world during the same period (10). Understandably, the scenario of the proportion of symptomatic to asymptomatic cases remains to vary between countries and care facilities. Few possible reasons for low symptomatic cases reported in the Nepalese population may be poor health-seeking behavior and utilization of tertiary health care services (11) for mild symptomatic cases, home isolation without a diagnosis, and a high rate of self-medication practices (12).

Among the provinces, Bagmati province $(n=144,278)$ has the highest number of confirmed cases in Nepal, followed by province no. $1(n=30,422)$ and Lumbini $(n=30,308)$ (Figure 1A). As depicted in Table 2, the confirmed cases of COVID-19 are distributed throughout the country in all the administrative districts. The total number of confirmed cases is highest in the Kathmandu district $(n=103,523)$ followed by Lalitpur $(n=16,106)$, Morang $(n=13,236)$, and Rupandehi $(n=9,708)$ districts and lowest in Manang $(n=20)$, Mugu $(n=37)$, Mustang $(n=43)$, and Humla $(n=44)$ districts (Table 2).

Among 268,948 confirmed cases, 174,193 were males, and 94,755 were females, with a male-to-female sex ratio of 1.85 . The largest number of infected cases was reported in the age group 21-30 years $(26.92 \%, n=72,396)$, followed by the age group of 31-40 years $(26.26 \%, n=70,648)$ (Figure 1B); however, the number of death cases was higher in the age group 61$70(23 \%, n=458)$ (Figure 1C). A higher death trend in old age is also observed in Europe, America, and Asian countries $(13,14)$. Overall, male death was $\sim 2.33$ times the death rate of females. Reports have indicated that men are at greater risk of around two time of acquiring severe outcomes of COVID-19, including hospitalizations, intensive care unit (ICU) admissions, and deaths (15). The enhanced susceptibility of males for COVID-19 associated adverse events may be correlated with the hormonal and immunological differences between males and females $(15,16)$. Among a total of 1,986 fatal cases (Male: $n=1,391$; female: $n=595)$, over half $(n=1,166)$ were observed in senior adults ( $\geq 60$ years). One early study among the Nepalese children suggested that male children were more commonly infected than female children (17).

Among 1,986 fatal cases (mean age: 66.15 years), 623 (31.37\%), $721(36.30 \%)$, and $642(32.32 \%)$ were with no report of comorbidities, with single comorbidities, and with multiple comorbidities, respectively. In cases with single comorbidities, the highest incidence was reported in respiratory disease ( $n=184)$ followed by hypertension $(n=117)$, renal disease ( $n=107)$, diabetes $(n=77)$, liver disease $(n=44)$, and cardiovascular disease $(n=36)$ (Figure 2). Similar results are reported from other parts of the world (18). The detailed epidemiological trend analysis of COVID-19 in Nepal is shown in Figure 3.

Geographically, Nepal is divided into three distinct ecological zones, mountain, hilly, and low-plain land from north to south. Politically, Nepal is divided into 7 provinces, 77 districts, and 753 local bodies. There were multiple peaks of active cases of COVID-19 in Nepal: active cases rapidly increased from early May to early July 2020, then increased slowly up to late July and increased at a higher rate again up to the end of December, and then decreased sharply (Figure 3A). The spatial distribution of COVID-19 confirmed cases, recovery, and deaths were compared (Figures 3B-D). Approximately, $64.84 \%$ of the total confirmed cases were reported from the hill regions, with single megacity Kathmandu contributing nearly half, $33.31 \%$ of lowland-plain areas, and $1.85 \%$ of Himalayan regions. The reported cases in the megacities are relatively higher than in the other regions. The higher number of cases in megacities may be correlated with dense populations in these areas (8). In the earlier months, the testing facilities and contact tracing were limited only to few districts, including the capital, Kathmandu, which gradually became available in other parts of the country. However, the testing frequency and testing facilities are still not homogeneous due to the lack of required technical resources and professional workforces $(19)^{9}$.

\section{THE RESPONSE OF NEPAL GOVERNMENT TO COVID-19}

Nepal has adopted many readiness and response-related initiatives at the federal, provincial, and local government levels to fight against COVID-19. Initially, the government had set health desks and allocated spaces for quarantine purposes at the international airport and at the borders, crossing points of entry (PoE) with India and China ${ }^{10}$, to withstand the influx of many possible infected individuals from India and other countries. The open border and the politico-religious relationship with India and migrant workers returning from the Middle East, and other countries were a source of rapid transmission to $\mathrm{Nepal}^{10}{ }^{11}$. The Nepal-China official border crossing points have remained closed since January 21, 2020. On March 24, 2020, the GoN imposed a complete "lockdown" of the country up to July 21, 2020. As part of the lockdown, businesses were closed, the restriction was imposed on movement within the country, workplaces were closed, travel was banned, and air transportation was halted ${ }^{11},{ }^{12}$. In addition, for COVID-19 preparedness and response, the GoN developed a quarantine procedure and issued an international travel advisory notice. Closing the border was critical as Nepal and India share open borders across which citizens travel freely for business and work.

\footnotetext{
${ }^{9}$ World Health Organization. (2020). WHO Nepal Situation Updates-16 on COVID-19, 2020. (2020). Available online at: https://www.who.int/docs/defaultsource/nepal-documents/novel-coronavirus/who-nepal-sitrep/16--who-nepal-sitrep-covid-19-07082020-final.pdf?sfvrsn=53c5360f_2 (accessed January 15, 2021).

${ }^{10}$ Bhattarai, KD. South Asian Voices: COVID-19 and Nepal's Migration Crisis. Available online at: https://southasianvoices.org/covid-19-and-nepals-migrationcrisis/ (accessed January 15, 2021).

${ }^{11}$ GRADA WORLD Nepal: Government announces nationwide lockdown from March 24-31/update. Available online at: https:/www.garda.com/crisis24/ news-alerts/326601/nepal-government-announces-nationwide-lockdown-frommarch-24-31-update-4 (accessed January 15, 2021).

${ }^{12}$ Gautam D. NDRC. Nepal's Readiness and Response to COVID-19. (2020). Available online at: https://www.preventionweb.net/files/71274_71274nepalsread inessandresponsetopa.pdf (accessed January 15, 2021).
} 


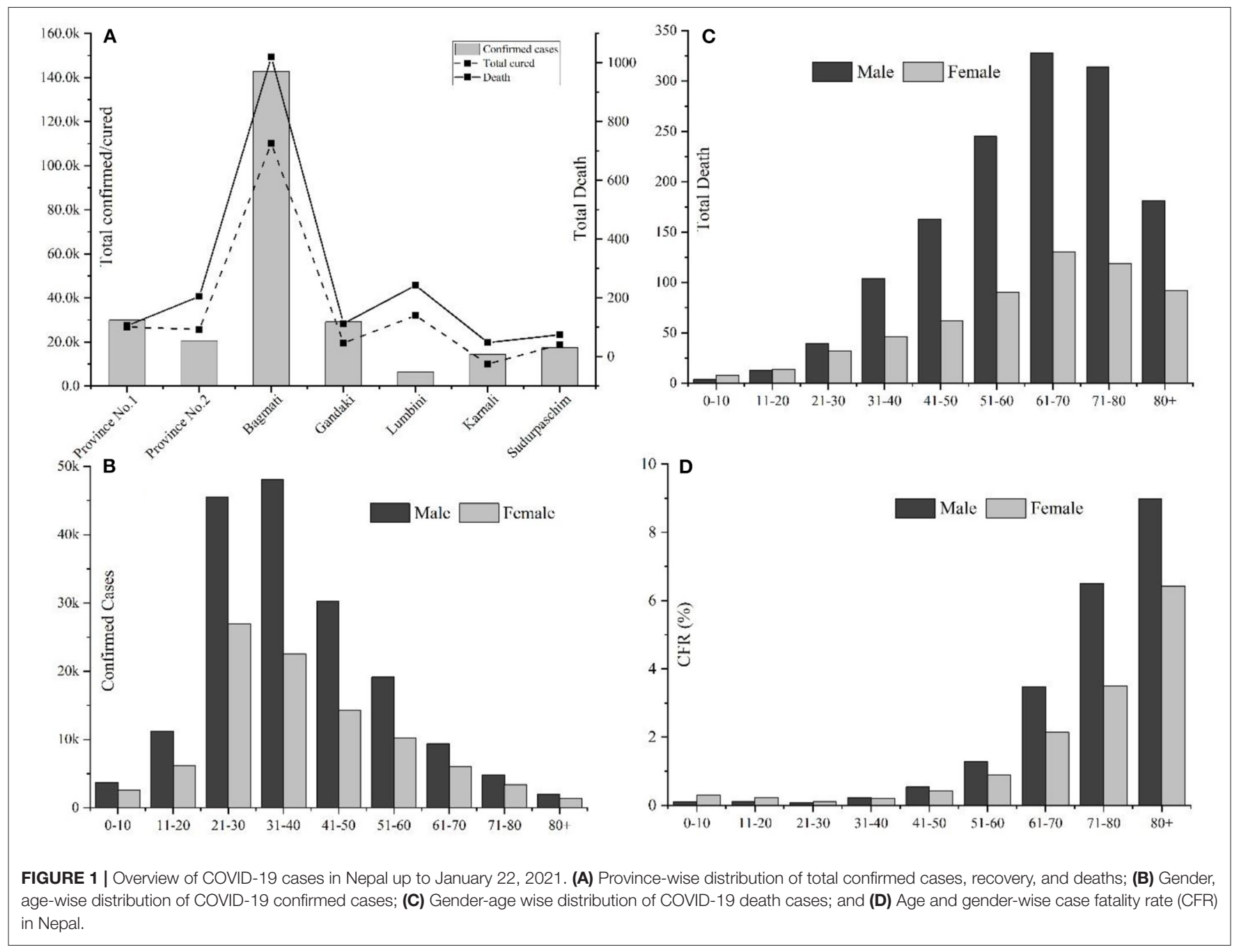

The GoN underestimated both the short and long-term impacts of border closure ${ }^{11}$. Around 2.8 million Nepali migrant workers work in India. Though the GoN discussed holding these workers in India with its Indian counterpart ${ }^{13}$, this plan did not materialize. Nepal has 1,690 $\mathrm{km}$-long open borders with India, which could not keep migrant workers long despite the restrictions implemented by both governments ${ }^{12}$. As a consequence, the majority of COVID-19 cases were in the districts along the Indo-Nepal border. The decision of the government to lockdown the country from March 10, 2020, without sufficient preparation pushed daily wage laborers in urban areas to lose their jobs, and, hence, they were trapped without food or money. Ultimately, after a couple of days of lockdown, both migrant workers and daily wage laborers started walking the long way home due to the economic crisis.

\footnotetext{
${ }^{13}$ Building Back Better (BBB) from COVID-19: World Vision Policy Brief on Building Back Better from COVID-19. (2020). Available online at: https://www. wvi.org/sites/default/files/202005/World\%20Vision\%20Policy\%20Brief\%20on \%20Building\%20Back\%20Better_25\%20May\%202020.pdf (accessed January 15, 2021).
}

As per the cabinet decision on March 25, 2020, Nepal established a COVID-19 response fund, developed a relief package $^{13}$, and distributed relief to families in need through a "one door policy"13 designed to reduce the COVID-19 impact; however, there were several gaps: the selection of families was unfair, GoN delayed the procurement of relief, relief packages did not include cash, and relief materials were inadequate and substandard ${ }^{14,15}$. The government has not adequately taken into account the impact of COVID-19 on the socio-economic sector. For instance, people participated in meetings, rallies, political demonstrations, and protests, where the virus could quickly spread among a large group of people. The government has, yet, to develop a stimulus package for social and economic recovery

\footnotetext{
${ }^{14}$ World Health Organization. WHO Nepal Situation Updates-1 on COVID-19, 2020. (2020). Available online at: https://www.who.int/docs/default-source/nepaldocuments/novel-coronavirus/who-nepal-sitrep/who-nepal- - sitrep-covid-1920apr2020.pdf?sfvrsn=c788bf96_2 (accessed January 15, 2021).

${ }^{15}$ GoN MoHP. Health Sector Emergency Response Plan COVID-19 Pandemic 2020. (2020). Available online at: https://www.who.int/docs/default-source/nepaldocuments/novel-coronavirus/health-sector-emergency-response-plan-covid19-endorsed-may-2020.pdf?sfvrsn=ef831f44_2 (accessed January 15, 2021).
} 
TABLE 2 | District wise distribution of confirmed cases, recoveries, and deaths due to COVID-19 and total population in Nepal.

\begin{tabular}{|c|c|c|c|c|c|c|c|c|c|c|c|}
\hline S.N. & District & Confirmed & Cured $^{\#}$ & Death ${ }^{\#}$ & Total Population* & S.N. & District & Confirmed $\#$ & Cured $^{\#}$ & Death ${ }^{\#}$ & Total Population* \\
\hline 1 & Kathmandu & 103,523 & 100,584 & 738 & 174,4240 & 40 & Lamjung & 1,142 & 1,127 & 2 & 167724 \\
\hline 2 & Lalitpur & 16,106 & 15,806 & 69 & 468,132 & 41 & Bajhang & 1,115 & 1,079 & 12 & 195159 \\
\hline 3 & Morang & 13,236 & 13,166 & 58 & 965,370 & 42 & Pyuthan & 1,103 & 1,076 & 15 & 228102 \\
\hline 4 & Rupandehi & 9,708 & 9,496 & 93 & 880,196 & 43 & Arghakhanchi & 1,049 & 1,023 & 4 & 197632 \\
\hline 5 & Bhaktapur & 9,245 & 9,139 & 60 & 304,651 & 44 & Sindhupalchok & 1,038 & 1,010 & 16 & 287798 \\
\hline 6 & Sunsari & 9,145 & 9,111 & 26 & 763,487 & 45 & Dolakha & 802 & 772 & 10 & 186557 \\
\hline 7 & Chitawan & 8,065 & 7,953 & 68 & 579,984 & 46 & Dadeldhura & 793 & 776 & 2 & 142094 \\
\hline 8 & Kaski & 7,668 & 7,544 & 20 & 492,098 & 47 & Baitadi & 735 & 706 & 3 & 250898 \\
\hline 9 & Kailali & 6,111 & 6,036 & 34 & 775,709 & 48 & Bajura & 733 & 724 & 5 & 134912 \\
\hline 10 & Banke & 5,123 & 4,960 & 45 & 491,313 & 49 & Udayapur & 682 & 669 & 2 & 317532 \\
\hline 11 & Jhapa & 5,033 & 4,993 & 23 & 812,650 & 50 & Salyan & 665 & 656 & 5 & 242444 \\
\hline 12 & Makawanpur & 4,348 & 4,290 & 42 & 420,477 & 51 & Sindhuli & 660 & 631 & 4 & 296192 \\
\hline 13 & Dang & 4,189 & 4,119 & 6 & 552,583 & 52 & Ramechhap & 590 & 567 & 19 & 202646 \\
\hline 14 & Kabhrepalanchok & 3,642 & 3,584 & 33 & 381,937 & 53 & Parbat & 546 & 489 & 28 & 146590 \\
\hline 15 & Parsa & 3,513 & 3,449 & 50 & 601,017 & 54 & Ilam & 495 & 482 & 5 & 290254 \\
\hline 16 & Dhanusha & 3,131 & 3,097 & 29 & 754,777 & 55 & Jumla & 475 & 454 & 2 & 108921 \\
\hline 17 & Nawalpur & 3,100 & 3,068 & 20 & 310,864 & 56 & Darchula & 426 & 409 & 15 & 133274 \\
\hline 18 & Sarlahi & 2,861 & 2,841 & 18 & 769,729 & 57 & Sankhuwasabha & 399 & 392 & 3 & 158742 \\
\hline 19 & Rautahat & 2,819 & 2,785 & 30 & 686,722 & 58 & Rolpa & 341 & 319 & 4 & 224506 \\
\hline 20 & Surkhet & 2,514 & 2,492 & 13 & 350,804 & 59 & Myagdi & 302 & 278 & 2 & 113641 \\
\hline 21 & Kapilbastu & 2,314 & 2,262 & 14 & 571,936 & 60 & Kalikot & 295 & 292 & 3 & 136948 \\
\hline 22 & Siraha & 2,294 & 2,270 & 20 & 637,328 & 61 & Okhaldhunga & 279 & 272 & 3 & 147984 \\
\hline 23 & Palpa & 2,246 & 2,214 & 2 & 261,180 & 62 & Dhankuta & 278 & 269 & 5 & 163412 \\
\hline 24 & Saptari & 2,187 & 2,141 & 13 & 639,284 & 63 & Rukum West & 267 & 255 & 12 & 154,272 \\
\hline 25 & Bara & 2,182 & 2,153 & 21 & 687,708 & 64 & Rasuwa & 238 & 227 & 1 & 43300 \\
\hline 26 & Mahottari & 2,073 & 2,041 & 29 & 627,580 & 65 & Khotang & 224 & 220 & 0 & 206312 \\
\hline 27 & Bardiya & 2,004 & 1,927 & 50 & 426,576 & 66 & Solukhumbu & 207 & 204 & 2 & 105886 \\
\hline 28 & Kanchanpur & 1,948 & 1,929 & 4 & 451,248 & 67 & Panchthar & 192 & 179 & 8 & 191817 \\
\hline 29 & Tanahu & 1,868 & 1,835 & 13 & 323,288 & 68 & Bhojpur & 166 & 163 & 3 & 182459 \\
\hline 30 & Dhading & 1,762 & 1,742 & 8 & 336,067 & 69 & Terhathum & 164 & 155 & 1 & 101577 \\
\hline 31 & Achham & 1,761 & 1,754 & 4 & 257,477 & 70 & Taplejung & 161 & 160 & 0 & 127461 \\
\hline 32 & Dailekh & 1,666 & 1,655 & 6 & 261,770 & 71 & Jajarkot & 123 & 119 & 1 & 171304 \\
\hline 33 & Parasi & 1,642 & 1,596 & 40 & 332,644 & 72 & Rukum East & 114 & 105 & 3 & 53184 \\
\hline 34 & Gorkha & 1,550 & 1,490 & 30 & 271,061 & 73 & Dolpa & 60 & 55 & 2 & 36700 \\
\hline 35 & Nuwakot & 1,530 & 1,456 & 17 & 277,471 & 74 & Humla & 44 & 37 & 4 & 50858 \\
\hline 36 & Doti & 1,448 & 1,444 & 1 & 211,746 & 75 & Mustang & 43 & 42 & 0 & 13452 \\
\hline 37 & Baglung & 1,275 & 1,241 & 7 & 268,613 & 76 & Mugu & 37 & 35 & 2 & 55286 \\
\hline 38 & Gulmi & 1,244 & 1,208 & 12 & 280,160 & 77 & Manang & 20 & 15 & 1 & 6538 \\
\hline 39 & Syangja & 1,201 & 1,184 & 10 & 289,148 & Total & & 268948 & 263546 & 1986 & 26494504 \\
\hline
\end{tabular}

Source: *National Population Census, 2011; "Ministry of Health and Population. COVID-19 Update. Available from: https://covid19.mohp.gov.np/ (Accessed on January 23, 2021).

at the micro and macro levels. As the government has allocated $\$ 788$ million for the health sector for the fiscal year (July-June 2020), a budget of $32 \%$ larger than the previous fiscal year, it should address the COVID-19 impact on the socio-economic front ${ }^{16}$. There is an opportunity to integrate all fragmented social protection schemes to strengthen socio-economic conditions and

${ }^{16}$ Gautam, D. The COVID-19 Crisis in Nepal: Coping Crackdown Challenges. National Disaster Risk Reduction Centre, Kathmandu, Nepal. Issue 3, 2020. Available online at: https://www.alnap.org/help-library/the-covid-19-crisis-innepal-coping-crackdown-challenges (accessed January 30, 2021). to emphasize more tremendous efforts, capacities, and resources to cope with the likely impacts of the COVID-19 pandemic ${ }^{16}$.

In addition, a minimal standard of quarantine as per the "Quarantine Operation and Management Protocol" (2076 B.S.) and "Standards for Home Quarantine" were imposed for all provinces ${ }^{16,17}$. The Sukraraj Infectious and Tropical Disease

${ }^{17}$ Gautam, D. Fear of COVID-19 Overshadowing Climate-Induced Disaster Risk Management. Available online at: https://www.spotlightnepal.com/2020/05/ 08/fear-covid-19-overshadowing-climate-induced-disaster-risk-management/ (accessed January 30, 2021). 


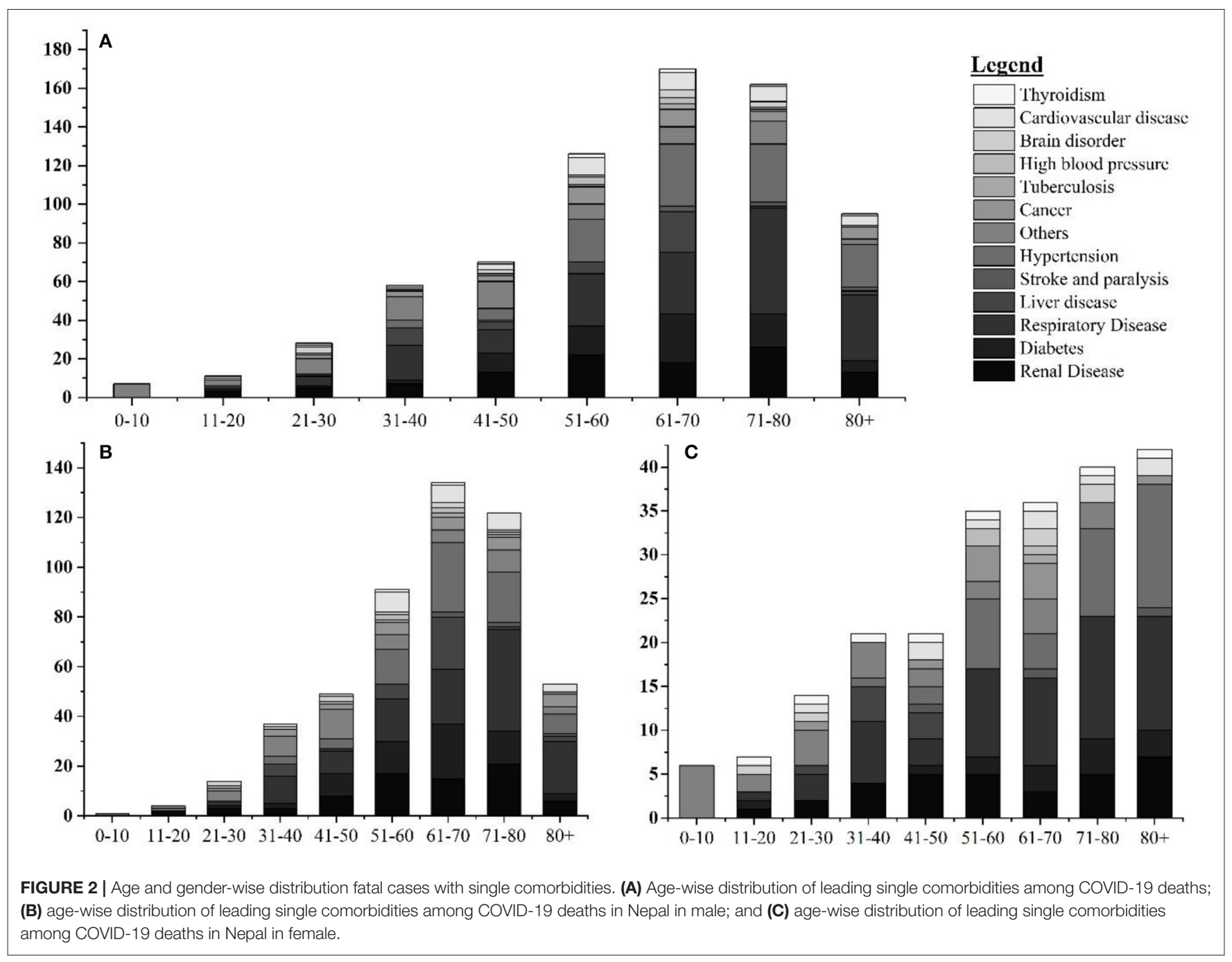

Hospital (SITDH) in Teku, Kathmandu, was designated by GoN as the primary hospital for COVID-19 cases along with Patan Hospital, the Armed Police Forces Hospital, in the Kathmandu Valley, followed by twenty-four hubs, and four satellite hospitals across the country ${ }^{18}$. Similarly, MoHP updated the National Public Health Laboratory (NPHL) capacity for confirmatory laboratory diagnosis of the COVID-19 from January 27, 2020, followed by the regional laboratory. The interim guideline for the establishing and operating of molecular laboratories for COVID-19 testing in Nepal was imposed to make uniformity in the test results ${ }^{14}$. Furthermore, the NPHL organized the training of trainers for laboratory staff in collaboration with the Medical Laboratory Association of $\mathrm{Nepal}^{19}$. Ministry of Health

\footnotetext{
${ }^{18}$ Pradhan TR. The Kathmandu Post. Nepal Goes Under Lockdown for a Week Starting 6am Tuesday. Available online at: https://kathmandupost.com/national/ 2020/03/23/nepal-goes- under-lockdown-for-a-week-starting-6am-tuesday (accessed January 30, 2021).

${ }^{19}$ World Health Organization. WHO Nepal Situation Updates-3 on COVID-19, 2020. (2020). Available online at: https://www.who.int/docs/default-source/nepaldocuments/novel-coronavirus/who-nepal-sitrep/who-nepal-- situpdate-3-covid19-06052020.pdf?sfvrsn=714d14c4_2 (accessed January 30, 2021).
}

and Population established two hotline numbers (1115 and 1133) to address public concerns, and prepared and disseminated regular press briefings, and improved its websites to channel appropriate information to the public. Besides, MoHP also conveyed decisions, notices, and situation updates periodically through its websites. Further, the Health Emergency Operation Centre (HEOC) of MoHP launched a "Viber communication group" to circulate updates on COVID-1911,13. Early testing and timely contact tracing are crucial restrictive policies to control the spreading of the SARS-CoV-2 virus $(20,21)$; however, in the earlier days of the pandemic, Nepal could not perform enough diagnostic tests and timely contact tracing; it resulted in a crucial time lag in identifying and isolating COVID-19 patients and caused delays in the ability of government to respond to the pandemic adequately. To alert and improve the testing and tracing response of the government, youth-led protests were carried out in different parts of the country ${ }^{20}$ Health Sector Emergency Response Plan was implemented in

\footnotetext{
${ }^{20}$ Jha IC. The Rising Nepal. MoHP Sets Forth Standards for Home Quarantine. Available online at: https://risingnepaldaily.com/featured/mohp-sets-forthstandards-for-home-quarantine (accessed January 30, 2021).
} 
May 2020, focusing on the COVID-19 pandemic. This plan intends to prepare and strengthen the health system response capable of minimizing the adverse impact of the COVID-19 pandemic. Government of Nepal devised a comprehensive plan on March 27, 2020, for quarantining people who arrived in Nepal from COVID-19 affected countries. The GoN had initially airlifted 175 Nepalese from six cities across Hubei Province of China on February 15, 2020, followed by Middle East countries, Australia, and so on ${ }^{13}$.

Ministry of Health and Population engaged in developing, endorsing, improving, and disseminating contextualized technical guidelines, standard operating procedures (SOPs), tools, and training in all other critical aspects of the response to COVID-19, for instance, surveillance, case investigation, laboratory testing, contact tracing, case detection, isolation and management, infection prevention and control, empowering health and community volunteers, media communication and community engagement, rational use of personal protective equipment (PPE), requirements of drugs and equipment for case management and public health interventions, and continuity of essentials services ${ }^{13}$ (15). The major contextualized technical guidelines, SOPs, tools, and training materials developed by GoN to respond to COVID-19 $11,22,23,24,25,26,27,28,29,30$ were listed in Table 3.

Ministry of Health and Population and supporting organizations, such as United Nations Development Program (UNDP), UNICEF, and World Vision managed crucial supplies of PPE, facemasks, gloves, and sanitizers to ensure the protection

\footnotetext{
${ }^{21}$ The Kathmandu Post. Youth-Led Protests Against the Government's Handling of Covid-19 Spread to Major Cities. (2020). Available online at: https:// kathmandupost.com/national/2020/06/12/youth-led-protests-against-thegovernment-s-handling-of-covid-19-spread-to-major-cities (accessed January 30, 2021).

${ }^{22}$ World Health Organization. WHO Nepal Situation Updates-2 on COVID-19, 2020. (2020). Available online at: https://www.who.int/docs/default-source/nepaldocuments/novel-coronavirus/who-nepal-sitrep/who-nepal- - sitrep-covid-1929apr2020.pdf?sfvrsn=dac001bf_2 (accessed January 30, 2021).

${ }^{23}$ World Health Organization. WHO Nepal Situation Updates-4 on COVID-19, 2020. (2020). Available online at: https://www.who.int/docs/default-source/ nepal-documents/novel-coronavirus/who-nepal-sitrep/who-nepal--situpdate-413052020.pdf?sfvrsn=630b68ea_6 (accessed January 30, 2021).

${ }^{24}$ World Health Organization. WHO Nepal Situation Updates-18 on COVID-19, 2020. (2020). Available online at: https://www.who.int/docs/default-source/nepaldocuments/novel-coronavirus/who-nepal-sitrep/18-who-nepal- sitrep-covid-1923082020.pdf?sfvrsn=6fb20500_2 (accessed February 5, 2021).

${ }^{25}$ World Health Organization. WHO Nepal Situation Updates-5 on COVID-19, 2020. (2020). Available online at: https://www.who.int/docs/default-source/nepaldocuments/novel-coronavirus/who-nepal-sitrep/5-who-nepal-- situpdate-covid19-20052020-final.pdf?sfvrsn=7552c8ba_4 (accessed February 5, 2021).

${ }^{26}$ World Health Organization. WHO Nepal Situation Updates-7 on COVID-19, 2020. (2020). Available online at: https://www.who.int/docs/default-source/nepaldocuments/novel-coronavirus/who-nepal-sitrep/7-who-nepal-- situpdate-covid19-03062020-final.pdf?sfvrsn=87f582d6_2 (accessed February 5, 2021).

${ }^{27}$ World Health Organization. WHO Nepal Situation Updates-8 on COVID-19, 2020. (2020). Available online at: https://www.who.int/docs/default-source/nepaldocuments/novel-coronavirus/who-nepal-sitrep/8-who-nepal--situpdate-covid19.pdf?sfvrsn=ce5ecb07_2 (accessed February 5, 2021).

${ }^{28}$ World Health Organization. WHO Nepal Situation Updates-10 on COVID-19, 2020. (2020). Available online at: https://www.who.int/docs/default-source/nepaldocuments/novel-coronavirus/who-nepal-sitrep/10-who-nepal--situpdatecovid-19-24062020.pdf?sfvrsn=c7f99a61_8 (accessed February 5, 2021).
}

of frontline workers and supporting staffs ${ }^{13,30,31,32}$. The frontline media of the nation increased online awareness programs via the involvement of celebrities, doctors, and experts of microbiology and infectious diseases on physical distancing and the importance and use of masks and sanitizers to prevent the COVID-19 contagion. In addition, camping programs were launched by the involvement of youth volunteers of the community in central $\mathrm{Nepal}^{33}$.

Government of Nepal received funds from the World Bank (\$29 million), the United States of America ( $\$ 1.8$ million), and Germany ( $\$ 1.22$ million) to keep people protected from COVID-19 through health systems preparedness, emergency response, and research. In addition, support from UNICEF and countries, including China, India, and the USA, in the form of emergency medical supplies and equipment were received within January 2020 to March 2020. Private companies, corporate houses, business organizations, and individuals have also contributed to the prevention, control, and treatment fund of coronavirus ( $\$ 13.8$ million), established by GoN to cope with COVID-19. The Prime Minister Relief Fund is also expected to be utilized. The GoN allowed international NGOs to divert $20 \%$ of their program budget to COVID-19 preparedness and response; for instance, the Social Welfare Council has allocated \$226 million $^{31,33,34,35,36,37}$.

The GoN has formed a committee to coordinate the preparedness and response efforts, including the MoHP, Ministry of Home Affairs, Ministry of Foreign Affairs, Ministry of Finance,

\footnotetext{
${ }^{29}$ World Health Organization. WHO Nepal Situation Updates-13 on COVID-19, 2020. (2020). Available online at: https://www.who.int/docs/default-source/nepaldocuments/novel-coronavirus/who-nepal-sitrep/13--who-nepal--situpdatecovid-19-17072020-v4.pdf?sfvrsn=fc0f19cc_2 (accessed February 5, 2021).

${ }^{30}$ World Health Organization. WHO Nepal Situation Updates-17 on COVID-19, 2020. (2020). Available online at: https://www.who.int/docs/default- source/nepaldocuments/novel-coronavirus/who-nepal-sitrep/17-who-nepal-sitrep-covid-1915082020.pdf? sfvrsn=68a53b32_2 (accessed February 10, 2021).

${ }^{31}$ UN. Nepal Information Platform, COVID-19 Nepal: Preparedness and Response Plan. Available online at: http://un.org.np/reports/covid-19-nepal-preparednessand-response-plan (accessed February 10, 2021).

${ }^{32}$ UNICEF for Every Child, Supporting COVID-19 Readiness and Response in the West of Nepal. Available online at: https://www.uniceforg/nepal/stories/ supporting-covid-19-readiness-and-response-west-nepal (accessed February 10, 2021).

${ }^{33}$ UNDP. Enhancing Public Awareness on COVID-19 Through Communications. Available online at: https://www.np.undp.org/content/nepal/en/home/ presscenter/articles/2020/Enhancing-public-awareness-of-COVID-19-throughcommunications.html (accessed February 10, 2021).

${ }^{34}$ The World Bank. The Government of Nepal and the World Bank sign \$29 Million Financing Agreement for Nepal's COVID-19 (Coronavirus) Response. Available online at: https://www.worldbank.org/en/news/press-release/2020/04/03/worldbank-fast-tracks-29-million-for-nepal-covid-19-coronavirus-response (accessed February 10, 2021).

${ }^{35}$ Khatri PP. The Rising Nepal. Govt Receives Over Rs 1.59 Bln In Anti-COVID-19 Fund. Available online at: https://risingnepaldaily.com/main-news/govt-receivesover-rs-159-bln-in-anti-covid-19-fund (accessed February 10, 2021).

${ }^{36}$ Dahal A. Govt Does U-Turn to Let NGOs Hand Out Medical Supplies, Food, Cash directly. Available online at: https://myrepublica.nagariknetwork.com/news/ govt-does-u-turn-to-let-ingos-hand-out-medical-supplies-food-cash-directly/ (accessed February 10, 2021).

${ }^{37}$ Rijal A. The Rising Nepal. China Gives Anti-Corona Medical Aid. Available online at: https://risingnepaldaily.com/main-news/china-gives-anti-corona-medical-aid (accessed February 10, 2021).
} 


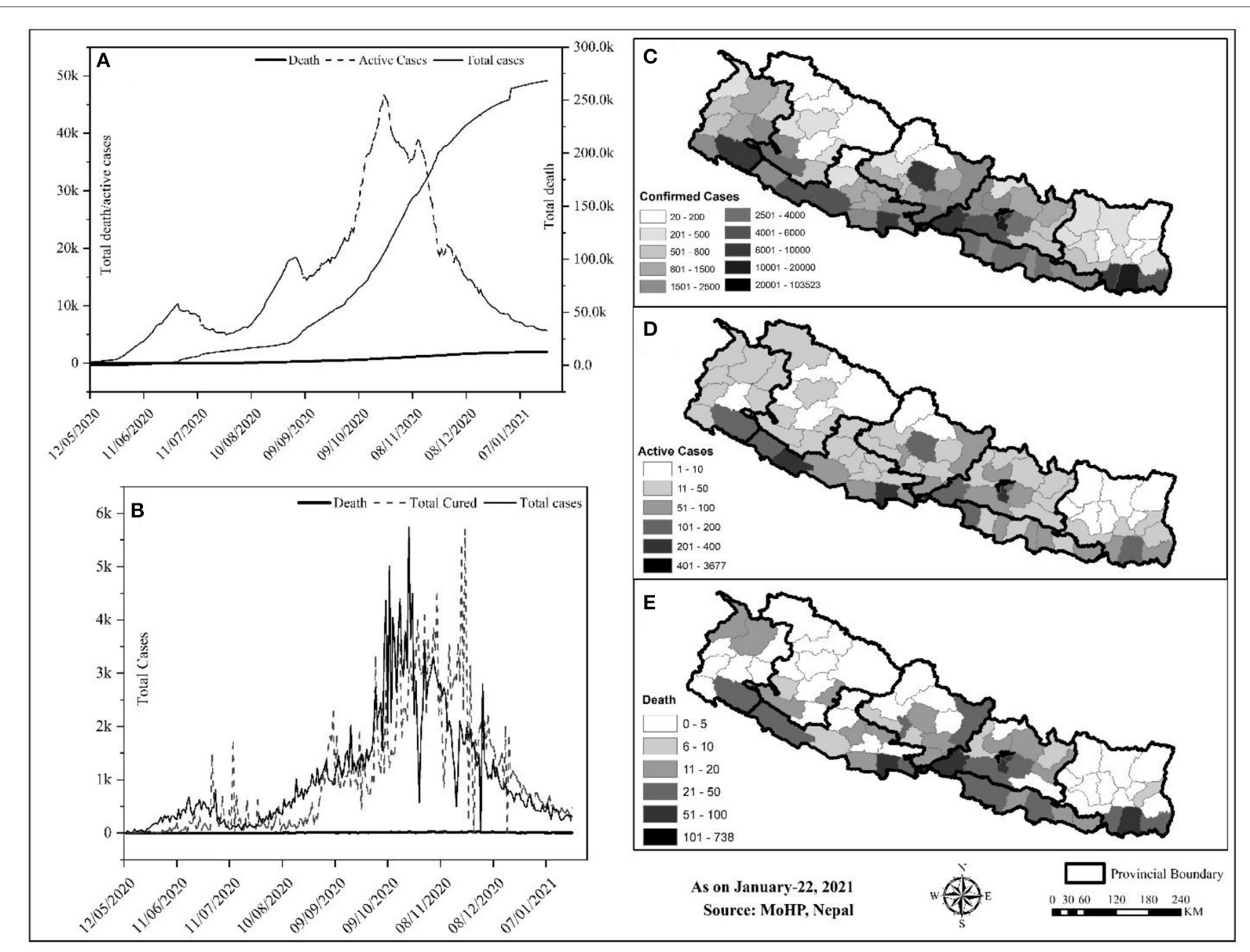

FIGURE 3 | Trend and spatial distribution of COVID-19 cases in Nepal. (A) Cumulative trend analysis of COVID-19 cases, (B) daily case wise trend analysis of COVID-19, (C-E) spatial distribution of infected, recovered, and death cases.

Ministry of Culture, Tourism and Civil Aviation, Ministry of Urban Development, Nepal Army, Nepal Police, and Armed Police Force. The Humanitarian Country Team (HCT) includes the Red Cross Movement and civil society organizations (national and international NGOs). Under the joint leadership of the office of Resident Coordinator and the WHO, the HCT has initiated contingency planning and preparedness interventions, including the dissemination of communications materials to raise community-level awareness across the country ${ }^{21}$. The clusters led by the GoN and co-led by the International Astronomical Search Collaboration (IASC) cluster leads and partners are working on finalizing contingency plans, which will be consolidated into an overall joint approach with the Government and its international partners. The UN activated the provincial focal point agency system to support coordination between the international community and the GoN at the provincial level ${ }^{21}$.

However, despite these robust efforts implemented by GoN, few lapses existed. Examples are the following: issues of inconsistent implementation of immigration policies usually at Indo-Nepal borders ${ }^{38,39,40}$, shortage and misuse of crucial protective suits and other supplies in hospitals, the ease and the end of lockdown, lack of poor infrastructure facilities, and continuous spread of COVID-19 across the country (19). The GoN decided to lift the lockdown effective from July 22, 2020, completely; however, the socio-administrative and health measures with the potential for high-intensity transmission (colleges, seminars, training, workshops, cinema halls, party palaces, dance bars, swimming pools, religious places, etc.)

${ }^{38}$ Nepali Sansar. Nepal Receives 23 Tons 'COVID-19 Medical Equip' As Gifts from India. (2020). Available online at: https://www.nepalisansar.com/coronavirus/ nepal-receives-23-tons-covid-19-medical-equip-as-gifts-from-india/ (accessed February 10, 2021).

${ }^{39}$ Koirala S, Bhattarai, S. My Republica. Protect Frontline Healthcare Workers. Available online at: https://myrepublica.nagariknetwork.com/news/protectfrontline-healthcare-workers/ (accessed February 10, 2021).

${ }^{40}$ Halder R. Lockdowns and national borders: How to manage the Nepal-India border crossing during COVID-19. Available online at: https://blogs.lse.ac.uk/ southasia/2020/05/19/lockdowns-and-national-borders-how-to-manage-thenepal-india-border-crossing-during-covid-19/ (accessed February 10, 2021). 


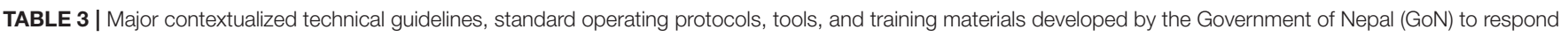
to COVID-19.

\begin{tabular}{|c|c|c|}
\hline S.No. & Date & Major contextualized technical guidelines, SOPs, tools, and training materials \\
\hline 1 & April, 2020 & $\begin{array}{l}\text { Guidelines for the management of front-line healthcare service providers and other workers involved in the } \\
\text { management of COVID-19 cases }\end{array}$ \\
\hline 2 & April, 2020 & Interim guidance for the operation of nutrition rehabilitation in the context of COVID-19 \\
\hline 3 & April, 2020 & $\begin{array}{l}\text { Interim pocketbook of clinical management of COVID-19 in the healthcare setting and Infection Prevention and Control } \\
\text { pocket booklet; interim guideline for the establishment and operationalization of molecular laboratory for COVID-19 } \\
\text { testing in Nepal; a guideline on safety measures to be taken at the point of entry }\end{array}$ \\
\hline 4 & May, 2020 & $\begin{array}{l}\text { Standard operating procedure of cleaning and decontamination of the ambulance used in COVID-19. The Department } \\
\text { of Ayurveda and alternative medicine has recently published national guidelines on preventive measures and } \\
\text { management protocol for COVID-19 in Nepal }\end{array}$ \\
\hline 5 & May, 2020 & $\begin{array}{l}\text { Guidelines for the management of dead bodies of people who died from COVID-19, COVID-19 cases isolation } \\
\text { management, and COVID-19 emergency medical teams (EMDT) mobilization }\end{array}$ \\
\hline 6 & June, 2020 & $\begin{array}{l}\text { MoHP has issued a guideline on minimum standards for donor agencies/partner organizations for COVID-19 logistics } \\
\text { support to the MoHP-2020 }\end{array}$ \\
\hline 7 & July, 2020 & $\begin{array}{l}\text { Guidance on testing of high-risk groups and random testing of people in communities at Kathmandu Valley including } \\
\text { other high-risk COVID-19 affected districts to detect community transmission }\end{array}$ \\
\hline 8 & August, 2020 & Standards for the service delivery of senior citizens in the context of COVID-19 \\
\hline
\end{tabular}

remained closed until the following directive as of September 1, 2020. Long route bus services and domestic and international passenger flights were halted until August 1,202011. A highlevel committee at the MoHP has requested all satellite hospitals (public, private, and others) to allocate $20 \%$ of their beds for COVID-19 cases. The respective hub hospitals coordinate with the HEOC and satellite hospitals to manage COVID-19 cases $^{42}$. After lifting lockdown for 3 weeks, the federal government has given authority to local administrations to decide on restrictions and lockdown measures as COVID-19 cases continue to rise. In addition, the authority to impose necessary restrictions if COVID-19 active cases surpass the threshold of 200 was given to the Chief District Officer $(C D O)^{43}$. Since March 2020, all the central hospitals, provincial hospitals, medical colleges, academic institutions, and hub-hospitals were designated to provide treatment care for COVID-19 cases. At this stage of operation, the major challenges for the COVID-19 response were managing quarantine facilities, lack of enough human resources, having limited laboratories for testing, and availability of limited stock of medical supplies, including PPEs ${ }^{14}$. To the best of our knowledge, this pandemic is the most extensive public health emergency the GoN faced in its recent history.

There is no doubt that GoN has taken major initiatives to fight the COVID-19 pandemic. The MoHP, together with

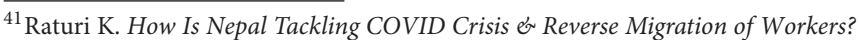
Available online at: https://www.thequint.com/voices/opinion/india-nepalborder-coronavirus- pandemic-migrant-workers- exodus-reverse-migrationunemployment (accessed February 10, 2021).

${ }^{42}$ World Health Organization. WHO Nepal Situation Updates-14 on COVID-19, 2020. (2020). Available online at: https://www.who.int/docs/default-source/nepaldocuments/novel-coronavirus/who-nepal-sitrep/14-- who-nepal- - sitrep-covid19-26072020.pdf?sfvrsn=65868c9e $\_2$ (accessed February 10, 2021).

${ }^{43}$ World Health Organization. WHO Nepal Situation Updates-19 on COVID-19, 2020. (2020). Available online at: https://www.who.int/docs/default-source/nepaldocuments/novel-coronavirus/who-nepal-sitrep/19-who-nepal-sitrep-covid-19. pdf?sfvrsn=c9fe7309_2 (accessed February 10, 2021).
}

associated national and international organizations are closely monitoring and evaluating the signs of outbreaks, challenges, and enforcing the plan and strategies to mitigate the possible impact; however, many challenges and difficulties, such as management of testing, hospital beds, and ventilators, quarantine centers, frontline staffs, movement of people during the lockdown, are yet to be solved $18,30,3844,45,46,47$. Therefore, in the opinion of the authors, we recommend some steps to be implemented as soon as possible to mitigate and lessen the impacts of COVID-19 (Table 4).

To strengthen its coordination mechanism, the government formed a team to monitor conditions and measures applied to control the outbreak; a COVID-19 coordination committee ${ }^{11}$ to coordinate the overall response, and a COVID-19 crisis management center ${ }^{14}$ to coordinate daily operations; however, these teams and committees did not function efficiently because roles and authorities were not delegated to ministries and government. A new institution was created, instead of using the National Disaster Risk Reduction and Management Authority $(\text { NDRRMA })^{48}$, which enhanced additional confusion. The

\footnotetext{
${ }^{44}$ Prasain S, Pradhan TR. The Kathmandu Post. Available online at: https:// kathmandupost.com/politics/2020/08/12/nepal-braces-for-a-return-to-lockeddown-life-as-rise-in-covid-19-cases-rings-alarm-bells (accessed February 10, 2021).

${ }^{45}$ NHPL. Information regarding Novel Corona Virus. (2020). Available online at: https://www.nphl.gov.np/page/ncov-related-lab-information (accessed February $10,2021)$

${ }^{46}$ NHRC. Assessment of Health-related Country Preparedness and Readiness of Nepal for Responding to COVID-19 Pandemic Preparedness and Readiness of Government of Nepal Designated COVID Hospitals. (2020). Available online at: http://nhrc.gov.np/wp-content/uploads/2020/06/Fact-sheet-Preparednessand-Readiness-of-Government- of-Nepal-Designated-COVID-Hospitals.pdf (accessed February 10, 2021).

${ }^{47}$ Koirala S. Comprehensive response to COVID 19 in Nepal. Available online at: https://en.setopati.com/blog/152612 (accessed February 10, 2021).

${ }^{48}$ National Disaster Risk Reduction and Management Authority, Ministry of Home Affairs, Government of Nepal. Available online at: https://covid19.ndrrma.gov.np/ (accessed February 10, 2021).
} 
TABLE 4 | Major steps taken by GoN and way forward in the response to COVID-19 outbreak.

\begin{tabular}{|c|c|c|c|}
\hline S. $\mathbf{N}$. & Date & Key steps taken by the GoN & Way ahead for Nepal \\
\hline 1 & January, 2020 & $\begin{array}{l}\text { Early warning and reporting system (EWARS) - daily and weekly } \\
\text { bulletin: Nepal }\end{array}$ & Increase the tracing and testing \\
\hline 2 & March, 2020 & $\begin{array}{l}\text { Formed a high-level coordination committee led by the Deputy Prime } \\
\text { Minister }\end{array}$ & $\begin{array}{l}\text { Impact analysis and current and post-pandemic } \\
\text { recovery plans and strategies }\end{array}$ \\
\hline 3 & March, 2020 & $\begin{array}{l}\text { Non-pharmacological interventions such as lockdown, social } \\
\text { distancing, quarantine, travel restrictions, media awareness }\end{array}$ & $\begin{array}{l}\text { Capacity building training for healthcare personal } \\
\text { and front-line workers }\end{array}$ \\
\hline 4 & March, 2020 & $\begin{array}{l}\text { Postponed less essential scheduled campaigns program, for instance, } \\
\text { Visit Nepal } 2020\end{array}$ & Training and monitoring for vaccination \\
\hline 5 & March, 2020 & $\begin{array}{l}\text { Discussion with experts to outline new strategies, frame action plans } \\
\text { and implement interventions }\end{array}$ & \\
\hline 6 & April, 2020 & $\begin{array}{l}\text { Collaboration, networking, and coordination with ministries, global } \\
\text { health sectors, NGOs, and INGOs. Instructed INGOs to divert up to } \\
20 \% \text { of their program budget to tackle COVID-19 }\end{array}$ & $\begin{array}{l}\text { Preparation of a robust database and information } \\
\text { system }\end{array}$ \\
\hline 7 & April, 2020 & Guidelines for SOP/Tools/Protocol for management of COVID-19 & \\
\hline 8 & April, 2020 & Establishment of grain banks for needy families & \\
\hline 9 & May, 2020 & $\begin{array}{l}\text { Acceptance of donation fund and set up an emergency COVID-19 fund } \\
\text { at the federal level, province level, and local level }\end{array}$ & $\begin{array}{l}\text { Strengthening of laboratory and hospital facilities, } \\
\text { and motivation for frontline staffs }\end{array}$ \\
\hline 10 & May, 2020 & $\begin{array}{l}\text { Significantly strengthened ICU, ventilators, laboratory facilities, } \\
\text { expansion of laboratory and testing }\end{array}$ & $\begin{array}{l}\text { Systematization of quarantine centers and isolation } \\
\text { beds }\end{array}$ \\
\hline 11 & August, 2020 & Procurement and supplies of PPE and Coronavirus Insurance Program & $\begin{array}{l}\text { Volunteer mobilization and increase awareness and } \\
\text { knowledge for citizens }\end{array}$ \\
\hline
\end{tabular}

MoHP is responsible for overall policy formulation, planning, organization, and coordination of the health sector at federal, provincial, district, and community levels during the COVID-19 pandemic situation. Allegedly, there is an opportunity to strengthen coordination among the tiers of governments by following protocols and guidance for effective preparedness and response. For example, some quarantine centers were so poorly run that, in turn, could potentially develop into breeding grounds for the COVID-19 transmission ${ }^{15}$.

Finally, this study only focuses on analyzing COVID-19 data extracted from the MoHP database for 1 year. Furthermore, we did not quantify the effectiveness of the strategies of GoN and the role of non-governmental organizations and authorities to combat COVID-19 in Nepal.

\section{CONCLUSION}

This study provides an insight into the impacts of the COVID-19 pandemic from the Nepalese context for the period of firstwave from January 2020 to January 2021. Despite the several initiatives taken by the GoN, the current scenario of COVID-19 in Nepal is yet to be controlled in terms of infections and mortality. A total of 268,948 confirmed cases and 1,986 deaths were reported in one year period. The maximum number of cases were reported from Bagmati province $(n=144,278)$, all of the 77 districts were affected. The cases showing highly COVID-specific symptoms were low $(<1 \%)$ in comparison with the reports across the globe (10), which may be because the average age of the Nepalese population is younger than many of the highly affected European countries. The other reasons may be differences in demographic characteristics, sampling bias, healthcare coverage, testing availability, and inconsistencies relating to the reporting of the data included in the current study. Both the number of infections and deaths are higher in males than in females. Despite the age, testing and positivity, hospital capacity and hospital admission criterion, demographics, and HDI index, the overall case fatality was reported to be less than in some other developed countries (Table 1). Consistent with reports from other countries $(22,23)$, the death rate is higher in the old age group (Figure 1). Spatial distribution displayed the cases, which are majorly distributed in megacities compared with the other regions of the country.

Based on this assessment, in addition to the WHO COVID-19 infection prevention and control guidance ${ }^{49}$, some recommendations, such as massive contact tracing, improving bed capacity in health care settings and rapid test, proper management of isolation and quarantine facilities, and advocacy for vaccines, may be helpful for planning strategies and address the gaps to combat against the COVID-19. Notably, the recommendations provided could benefit the governmental bodies and concerned authorities to take the appropriate decisions and comprehensively assess the further spread of the virus and effective public health measures in the different provinces and districts in Nepal. In this review, we have summarized the ongoing experiences in reducing the spread of COVID-19 in Nepal. The Nepalese response is characterized by nationwide lockdown, social distancing, rapid response, a

\footnotetext{
${ }^{49}$ World Health Organization. Infection Prevention and Control Guidance - (COVID-19). (2021). Available online at: https://www.who.int/emergencies/ diseases/novel-coronavirus-2019/advice-for-public (accessed February 10, 2021).
} 
multi-sectoral approach in testing and tracing, and supported by a public health response. Overall, the broader applicability of these experiences is subject to combat the COVID-19 impacts in different socio-political environments within and across the country in the days to come.

\section{AUTHOR CONTRIBUTIONS}

BB: Conceptualization, writing, and original draft preparation. $\mathrm{KB}, \mathrm{BB}$, and $\mathrm{AG}$ : data curation. $\mathrm{BB}, \mathrm{RP}, \mathrm{TB}, \mathrm{SD}, \mathrm{NP}$, and $\mathrm{DG}$ :

\section{REFERENCES}

1. Jayaweera M, Perera H, Gunawardana B, Manatunge J. Transmission of COVID-19 virus by droplets and aerosols: a critical review on the unresolved dichotomy. Environ Res. (2020) 188:109819. doi: $10.1016 /$ j.envres.2020.109819

2. Zheng J. SARS-CoV-2: an emerging coronavirus that causes a global threat. Int J Biol Sci. (2020) 16:1678-85. doi: 10.7150/ijbs. 45053

3. Islam N, Sharp SJ, Chowell G. Physical distancing interventions and incidence of coronavirus disease 2019: natural experiment in 149 countries. BMJ. (2020) 370:27-43. doi: 10.1136/bmj.m2743

4. Gupta A, Singla M, Bhatia H, Sharma V. Lockdown-the only solution to defeat COVID-19. Int J Diabetes Dev Ctries. (2020) 6:1-2. doi: 10.1007/s13410-020-00826-3

5. Lu G, Razum O, Jahn A, Zhang Y, Sutton B, Sridhar D, et al.. COVID-19 in Germany and China: mitigation versus elimination strategy. Glob. Health Action. (2021). 14:1875601. doi: 10.1080/16549716.2021.1875601

6. The Lancet. COVID-19: too little, too late. Lancet. (2020) 395:P755. doi: 10.1016/S0140-6736(20)30522-5

7. Bastola A, Sah R, Rodriguez-Morales AJ, Lal BK, Jha R, Ojha HC, et al. The first 2019 novel coronavirus case in Nepal. Lancet Infect Dis. (2020) 20:279-80. doi: 10.1016/s1473-3099(20)30067-0

8. Dhakal S, Karki S. Early epidemiological features of COVID19 in Nepal and public health response. Front. Med. (2020) 7:524. doi: 10.3389/fmed.2020.00524

9. Panthee B, Dhungana S, Panthee N, Paudel A, Gyawali S, Panthee S. COVID-19: the current situation in Nepal. New Microbes New Infect. (2020) 37:100737. doi: 10.1016/j.nmni.2020.100737

10. Oran DP, Topol EJ. The proportion of SARS-CoV-2 infections that are asymptomatic: a systematic review. Ann Intern Med. (2021) 174:65562. doi: 10.7326/M20-6976

11. Bhattarai S, Parajuli SB., Rayamajhi RB, Paudel IS, Jha N. Clinical health seeking behavior and utilization of health care services in eastern hilly region of Nepal. J Coll Med. Sci Nepal. (2015). 11:8-16. doi: $10.3126 / \mathrm{jcmsn} . v 11 \mathrm{i} 2.13669$

12. Paudel S, Aryal B. Exploration of self-medication practice in Pokhara valley of Nepal. BMC Public Health. (2020) 20:714. doi: 10.1186/s12889-020-08860-w

13. Ioannidis JPA, Axfors C. Contopoulos-Ioannidis DG. Populationlevel COVID-19 mortality risk for non-elderly individuals overall and for non-elderly individuals without underlying diseases in pandemic epicenters. Environ Res. (2020) 188:109890. doi: 10.1016/j.envres.2020. 109890

14. Cortis D. On determining the age distribution of COVID-19 pandemic. Front. Publ. Health. (2020) 8:202. doi: 10.3389/fpubh.2020. 00202

15. Gebhard C, Regitz-Zagrosek V, Neuhauser HK, Morgan R, Klein SL. Impact of sex and gender on COVID-19 outcomes in writing, review, and editing. All authors contributed to the article and approved the submitted version.

\section{ACKNOWLEDGMENTS}

The authors are grateful to the Ministry of Health and Population (MoHP), Government of Nepal, for supporting data in this research. We are thankful to the reviewers for their meticulous comments and suggestions, which helped to improve the manuscript.
Europe. Biol Sex Differ. (2020) 11:29. doi: 10.1186/s13293-020-00 304-9

16. Sharma G, Volgman AS, Michos ED. Sex differences in mortality from COVID-19 pandemic: are men vulnerable and women protected? JACC Case Rep. (2020) 2:1407-10. doi: 10.1016/j.jaccas.2020.04.027

17. Sharma AK, Chapagain RH, Bista KP, Bohara R, Chand B, Chaudhary NK, et al. Epidemiological and clinical profile of COVID-19 in Nepali children: an initial experience. J Nepal Paediatr Soc. (2020) 40:2029. doi: 10.3126/jnps.v40i3.32438

18. Piryani RM, Piryani S, Shah JN. Nepal's response to contain COVID-19 infection. J Nepal Health Res Counc. (2020) 18:12834. doi: 10.33314/jnhrc.v18i1.2608

19. Rayamajhee B, Pokhrel A, Syangtan G. How well the government of nepal is responding to COVID-19? An experience from a resource-limited country to confront unprecedented pandemic. Front Public Health. (2021) 9:597808. doi: 10.3389/fpubh.2021.597808

20. Kretzschmar ME, Rozhnova G, Bootsma MC, van Boven M, van de Wijgert $\mathrm{JH}$, Bonten MJ. Impact of delays on effectiveness of contact tracing strategies for COVID-19: a modelling study. Lancet Public Health. (2020) 5:e452-9. doi: 10.1016/S2468-2667(20)30157-2 21

21. Contreras S, Biron-Lattes JP, Villavicencio HA, Medina-Ortiz D, Llanovarced-Kawles N, Olivera-Nappa Á. Statistically-based methodology for revealing real contagion trends and correcting delay-induced errors in the assessment of COVID-19 pandemic. Chaos Solit Fract. (2020). 139:110087. doi: 10.1016/j.chaos.2020.110087

22. Levin AT, Hanage WP, Owusu-Boaitey N, Cochran KB, Walsh SP, MeyerowitzKatz G. Assessing the age specificity of infection fatality rates for COVID19: systematic review, meta-analysis, and public policy implications. Eur $J$ Epidemiol. (2020) 35:1123-38. doi: 10.1007/s10654-020-00698-1

23. O'Driscoll M, Dos Santos GR, Wang L, Cummings DA, Azman AS, Paireau J, et al. Age-specific mortality and immunity patterns of SARS-CoV-2. Nature. (2021). 590:140-5. doi: 10.1038/s41586-020-2918-0

Conflict of Interest: KB and AG were employed by Nepal Environment and Development Consultant Pvt. Ltd., in Kathmandu, Nepal.

The remaining authors declare that the research was conducted in the absence of any commercial or financial relationships that could be construed as a potential conflict of interest.

Copyright (๑) 2021 Basnet, Bishwakarma, Pant, Dhakal, Pandey, Gautam, Ghimire and Basnet. This is an open-access article distributed under the terms of the Creative Commons Attribution License (CC BY). The use, distribution or reproduction in other forums is permitted, provided the original author(s) and the copyright owner(s) are credited and that the original publication in this journal is cited, in accordance with accepted academic practice. No use, distribution or reproduction is permitted which does not comply with these terms. 